\title{
Fajar Historia
}

\section{Jurnal Ilmu Sejarah dan Pendidikan}

https://e-journal.hamzanwadi.ac.id/index.php/fhs/index

ISSN: 2549-5585 (online), Vol. 5 No. 2 Desember 2021, hal 171-182

\section{Refleksi Guru Terhadap Problem Keragaman Media Daring dalam Pembelajaran Sejarah}

\author{
Yeni Kurniawati ${ }^{1}$, Wawan Darmawan ${ }^{2}$, Ayi Budi Santosa ${ }^{3}$ Labibatussolihah $^{4 *}$ \\ ${ }^{1}$ Universitas Pendidikan Indonesia; yenikurniawati@upi.edu \\ ${ }^{2}$ Universitas Pendidikan Indonesia; wawand@upi.edu \\ ${ }^{3}$ Universitas Pendidikan Indonesia; ayibud@upi.edu \\ ${ }^{4}$ Universitas Pendidikan Indonesia; labibatussolihah@upi.edu \\ *Korespondensi
}

Dikirim: 16-11-2021; Diterima: 02-12-2021; Diterbitkan: 30-12-2021

\begin{abstract}
This article aims to explain the problem of the variety of online media used by teachers during online history learning. This problem arises because there is no standard provision for online media that must be used by teachers. So that teachers can freely take advantage of various free and paid online media or even develop media independently. The research method used is a survey using a questionnaire distributed by random sampling technique for one month to 41 respondents spread over nine provinces in Indonesia. The results of the descriptive statistical analysis show that teachers mix and match the use of online media in accordance with the learning objectives. Another finding is that it is understood that each media has its own advantages and disadvantages. The relatively similar impression in sorting and selecting various online media is described in this article. The most popular online media for planning are Google Classroom and WhatsApp Group. As for the implementation of learning, namely Zoom Meeting and Google Meeting. Online media for learning evaluation using Quizizz.
\end{abstract}

Keywords: history learning; online learning; online media

Abstrak: Artikel ini bertujuan untuk menjelaskan persoalan ragam media daring yang digunakan oleh guru selama pembelajaran sejarah daring. Persoalan ini muncul karena tidak adanya ketentuan baku akan media daring yang wajib digunakan oleh guru. Sehingga guru dapat leluasa memanfaatkan berbagai media daring yang gratis maupun berbayar atau bahkan menggembangkan media secara mandiri. Metode penelitian yang digunakan yaitu survei dengan menggunakan angket yang disebarkan dengan teknik random sampling selama satu bulan kepada 41 responden yang tersebar di sembilan provinsi di Indonesia. Hasil dari analisis statistis deskriptif menunjukkan bahwa guru memadupadankan penggunaan media daring yang sesuai dengan tujuan pembelajaran. Temuan lainnya yaitu telah dipahami bahwa setiap media memiliki kelebihan dan kekuranganya masing-masing. Kesan yang relatif sama dalam memilah dan memilih berbagaimedia daring diuraikan dalam artikel ini. Media daring yang paling diminati untuk perencanaan yaitu Google Classroom dan WhatsApp Group. Sedangkan untuk pelaksanaan pembelajaran yaitu Zoom Meeting dan Google Meeting. Media daring untuk evaluasi pembelajaran menggunakan Quizizz.

Kata Kunci: belajar daring; media daring; pembelajaran sejarah 


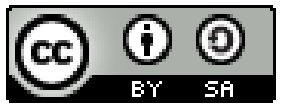

Jurnal Fajar Historia is licensed under a Creative Commons AttributionShareAlike 4.0 International License.

\section{Pendahuluan}

Pandemi yang melanda saat ini membawa dampak terhadap dunia pendidikan. Dampak yang paling terasa yakni dalam kegiatan belajar mengajar. Proses yang biasa dilakukan secara tatap muka langsung beralih dengan memanfaatkan gadget untuk belajar. Sejak pandemi Covid19 melanda Indonesia pada Maret tahun 2020 muncul istilah Belajar Dari Rumah (BDR), Pembelajaran Jarak Jauh (PJJ), dan belajar online atau dalam jaringan (daring). Sehingga sejak saat itu, pembelajaran dilakukan secara tatap maya.

Pembelajaran daring menjadi satu-satunya cara yang dapat dilakukan untuk meningkatkan pendidikan ketika pemerintah menerapkan social distancing dalam berbagai aspek termasuk pendidikan (Syarifudin, 2020). Perubahan yang serba cepat dan mendadak ini dapat dianggap sebagai peluang, hambatan atau tantangan tergantung pada sudut pandangnya. Penelitian yang dilakukan oleh Satrianingrum and Prasetyo (2020) melihat bahwa Guru PAUD mengalami kesulitan mengontrol siswa karena memiliki gaya belajar visual. Berbeda pada tingkat sekolah menengah, keterbatasan yang dialami oleh SMPN 2 Karambit dalam menerapkan kemandirian belajar daring siswa tanpa bergantung pada guru masih dapat dikategorikan cukup baik (Wati, 2020). Sedangkan pada tingkat SMA mengalami penurunan motivasi belajar selama pembelajaran daring di tengah pandemi ini (Cahyani et al., 2020). Selain itu, hasil penelitian Anis et al (2021) ditemukan bahwa saat pembelajaran daring juga terjadi penurunan hasil belajar di SMAN 10 Banjarmasin yang diakibatkan masih dalam proses adaptasi. Lain halnya dengan suasana pembelajaran di tingkat universitas, mahasiswa dapat beradaptasi serta merasa tertantang selama pembelajaran daring dan dijadikan pengalaman sebagai calon guru (Jamaluddin et al., 2020). Hasil penelitian-penelitian tersebut menunjukkan berbagai jenjang pendidikan telah melakukan pembelajaran secara daring. Akan tetapi belum ada yang melakukan refleksi akan berbagai media daring yang digunakan oleh guru selama PJJ, khususnya dalam pembelajaran sejarah.

Padahal setiap satuan pendidikan memiliki pengalaman yang berbeda-beda. Menurut Wahyono, Husamah dan Budi (2020) perlu adanya kurikulum yang bersifat fleksibel serta dapat sesuai dengan beban siswa baik dari segi waktu maupun materi. Mengahadapi situasi ini, pemerintah memberlakukan kurikulum darurat dengan menyederhanakan Kompetensi Dasar di seluruh jenjang. Pada tahap pelaksanaannya disesuaikan dengan kondisi dan sarana-prasarana sekolah masing-masing. Media daring menjadi solusi untuk membantu siswa untuk belajar. Berdasarkan penelitian yang dilakukan (Indiani, 2020) guru merupakan faktor penentu dalam optimalisasi penggunaan media daring dalam pembelajaran. Media daring yang dimaksud adalah fitur dalam google, zoom meeting, google classroom, telegram, WhatsApp, LMS dan lainnya. Meskipun, secara umum tidak ada ketentuan baku akan media yang harus digunakan oleh guru, namun secara internal ada aturan yang diharuskan oleh pihak sekolah dan ada juga yang membebaskan guru untuk mengekplorasi media daring yang akan digunakan. 
Perbedaan penggunaan media online dalam pembelajaran tingkat SMA di berbagai daerah menjadikan proses pembelajaran sangat bergantung pada kemampuan guru dalam mengemas pembelajaran yang menarik. Penelitian ini terfokus untuk mengetahui media daring apa saja yang paling diminati oleh guru dan melihat ungkapan kesan guru atas berbagai media tersebut. Sehingga persoalan yang dihadapi guru akan ragam media selama pembelajaran sejarah daring menjadi tujuan dalam penelitian ini. Berbagai macam karakter guru mempengaruhi caranya dalam memutuskan penggunaan media daring karena setiap guru memiliki kapasitas pengoperasian teknologi yang berbeda-beda. Dampaknya akan terjadi ketimpangan antara guru yang mampu dengan yang kurang dalam mengeksplor media daring. Ketimpangan ini dapat disebabkan oleh minimnya informasi terbaru yang membahas mengenai media daring.

Respon akan permasalahan tersebut, diperlukan penjelasan yang menunjukkan kelebihan dan kekurangan dari berbagai media daring yang telah digunakan. Selanjutnya diidentifikasi dengan mengkategorikan kedalam tiga tahap proses pembelajaran yaitu perencanaan, pelaksanaan dan evaluasi. Hasilnya dapat menjadi bahan evaluatif bagi guru maupun peneliti sejarah yang akan memilih media daring sesuai dengan langkah pembelajaran. Urgensi penelitian ini untuk dapat peran serta mengotimalkan pembelajaran sejarah yang memanfaatkan media daring lebih baik lagi yang sesuai dengan kebutuhan siswa maupun guru serta tuntutan zaman.

\section{Metode Penelitian}

Metode penelitian survei digunakan untuk mengumpulkan informasi terkait penggunaan aplikasi pembelajaran yang digunakan oleh guru sejarah di tengah pembelajaran daring. Ketegori survei deskriptif dipilih karena penelitian yang dilakukan berupaya menjelaskan yang terjadi saat ini (Morissan, 2014). Angket yang disusun peneliti disebarkan menggunakan teknik random sampling melalui kegiatan seminar dan WhatsApp Group selama satu bulan. Terdapat 41 responden yang terdiri dari 21 Wanita dan 20 Pria yang tersebar dari berbagai provinsi diantaranya Jawa Barat, Jawa Tengah, Jawa Tengah, Jawa Timur, Aceh, Jambi, Sumatera Selatan, Kepualaun Riau, dan Kalimantan Selatan. Temuan hasil penelitian dianalisis menggunakan statistik deskriptif yang terbatas pada mendeskripsikan data yang terkumpul.

\section{Hasil Penelitian}

Pembelajaran daring yang berlangsung sejak awal tahun 2020 menantang guru-guru untuk adaptif akan situasi baru. Perubahan ini memberikan ruang kepada aplikasi- aplikasi online yang berbayar maupun gratis untuk dimanfaatkan oleh guru guna menunjang proses belajar mengajar. Berdasarkan angket yang disebarkan oleh peneliti, dapat diketahui pertimbangan guru dalam memilah dan memilih aplikasi yang akan digunakan dalam pembelajaran Sejarah di SMA, MAN dan SMK. Peneliti mengidentifikasi kedalam tiga aspek diantaranya perencanaan, pelaksanaan, dan evaluasi pembelajaran.

Sebanyak 22\% guru menggunakan Google Classroom dan WhatsApp Group sebagai aplikasi perencanaan. Zoom Meeting dan Google Meeting digunakan untuk pelaksanaan. Sedangkan untuk evaluasi pembelajaran menggunakan Quizizz. Kelima aplikasi tersebut 
dianggap paling menunjang dalam pembelajaran sejarah, seperti yang dapat dilihat dalam Gambar 1 di bawah ini.

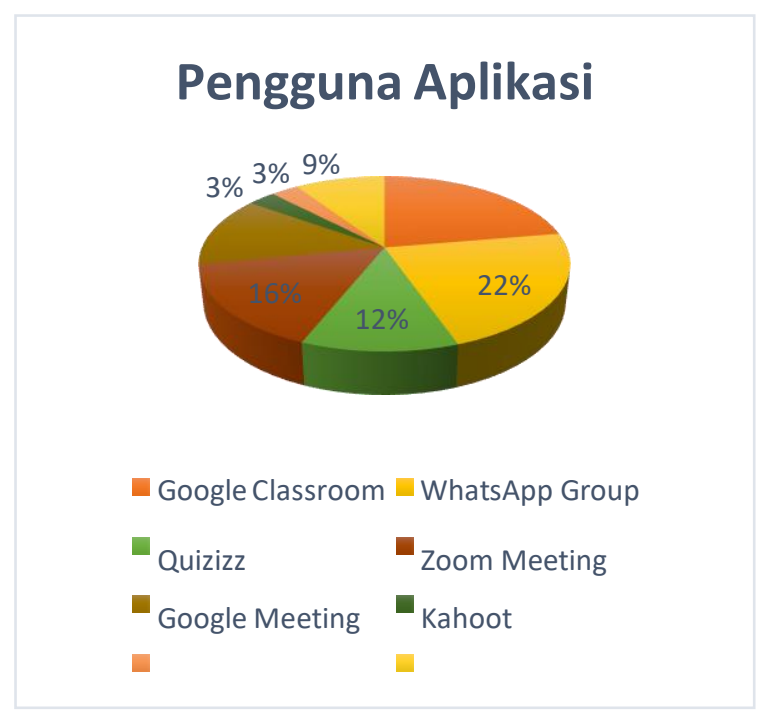

Gambar 1. Presentase pengguna aplikasi

Penggunaan Google Classroom (GC) dan WhatsApp Group (WAG) menjadi diminati karena kedua aplikasi tersebut yang sederhana, mudah digunakan, menggunakan kuota dengan minim, dianjurkan oleh pihak sekolah dan familiar bagi guru dan siswa. Akantetapi, ditengah kemudahan tersebut terdapat kekurangan yaitu GC belum terdapat fitur memeriksa kehadiran siswa, sulit ketika mengunggah video yang ukuran besar, tampilan kurang menarik, guru tidak mengetahui siswa yang telah membaca materi. SedangkanWAG terbatas pada chatting, voice note dan mengirim gambar/video. Guru tidak bisa melihat secara langsung expresi siswa. Selain itu, guru tidak bisa melihat secara langsung mana saja siswa yang sedang menyimak intruksi guru dalam WAG.

Sedangkan penggunaan Zoom Meeting sebesar 16\% dan Google Meeting sebesar 13\% menunjukkan ada perbedaan 3\%. Hasil penelusuran menunjukkan bahwa tatap maya dilakukan untuk menjelaskan materi-materi yang paling penting dan mudah digunakan untuk presentasi. Selain itu, tatap maya memudahkan guru untuk berinteraksi dan mengetahui kehadiran siswa secara real time. Perbedaan 3\% disebabkan oleh google meeting acapkali 'ngelag' atau ketinggalan saat video conference, tetapi aplikasi ini lebih ekonomis dibandingkan dengan zoom meeting yang menggunakan kuota lebih besar dan berbayar.

Quizizz sudah tidak asing lagi digunakan guru dalam pembelajaran. Namun, aplikasi ini masih memiliki daya tarik bagi guru ditengah pembelajaran daring saat ini. Alasannya karena mudah digunakan dalam proses penilaian. Guru dapat memperoleh nilai siswa secara langsung, ditambah fitur yang terus diupdate seperti terintegrasinya gengan Google Class Room menjadikannya mudah diakses oleh guru maupun siswa. Namun satu sisi, perlu memuliki koneksi yang baik dan tidak bisa digunakan tatap maya sehingga tidak terjalin interaksi antara guru dan siswa.

Selain aplikasi yang ada, terdapat juga sekolah-sekolah yang telah mengembangkan 
Learning Managemen System (LMS) secara mandiri. LMS ini wajib digunakan oleh setiap guru. Pengembaangan LMS didasari oleh fitur yang disediakan sesuai dengan kebutuhan. Meskipun masih sederhana, namun LMS mudah dioperasikan oleh siswa maupun guru. Selain itu, kuota yang digunakan tidak banyak. Sehingga terjangkau untuk digunakan dalam pembelajaran. Berhubung LMS merupakan hal baru yang dikembangkan oleh sekolah, sehingga video conference belum terfasilitasi dengan baik.

Hal unik lainnya ditemukan oleh peneliti yaitu terdapat sekolah yang sama sekali tidak menggunakan aplikasi dalam menunjang pembelajaran. Penyebab utama jaringan yang tidak tersedia, sehingga ketika kebanyakan sekolah menerapkan sistem pembelajaran daring. Sekolah ini tetap melakukan tatap muka.

Adapun aplikasi lain yang digunakan oleh guru diantaranya pertama, telegram sebagai media untuk melakukan kuis. Namun terbatas hanya dapat diikuti untuk 20 siswa. Kedua, bernama zoho form untuk memeriksa kehadiran siswa. Ketiga, google form yang dimanfaatkan untuk mengetahui kehadiran siswa dan digunakan untuk evaluasi. Selanjutnya terdapat Cisco Webex, Kahoot, Edmodo, schoology, Microsoft teams, wordwall.net, fasilitas google (google slides, google sites, dan google maps), dan website/blog buatan guru.

Meskipun terdapat kelebihan dan kekurangan dari setiap aplikasi. Peneliti menemukan upaya kreativitas guru dalam mengemas pembelajaran daring Sejarah dengan memadupadankan antar aplikasi sehingga saling melengkapi. Selain itu, guru maupun siswa mengoptimalkan bantuan kuota pemerintah.

\section{Pembahasan}

Pembelajaran di Abad ke-21 dikenal sebagai abad pengetahuan yang merupakan landasan utama segala aspek kehidupan, termasuk dunia pendidikan. Kegiatan pembelajaran mengalami perubahan dari waktu ke waktu yang dipengaruhi oleh berkembangnya pengetahuan, teknologi dan tuntutan zaman. Hasan (2019) menjelaskan bahwa terdapat perubahan tujuan pendidikan sejarah yang dikembangkan untuk menyiapkan siswa dalam melihat, berperilaku, berpikir, berkomunikasi, berkolaborasi, dan keterampilan lain yang diperlukan untuk mengembangkan kualitas hidup yang lebih baik di masa depan. Hasan (2018) juga merumuskan kemampuan Abad ke-21 yang dapat dilihat pada Tabel 1.

Tabel 1. Kemampuan Abad ke-21

\begin{tabular}{ll}
\hline \multicolumn{1}{c}{ Skills } & \multicolumn{1}{c}{ Description } \\
\hline Critical Thinking & $\begin{array}{l}\text { Competency for conceptualizing, appling, analzing, appling } \\
\text { deductive and inductive thinking }\end{array}$ \\
\hline Creativity & $\begin{array}{l}\text { Competency for developing solution, ideas, concept, } \\
\text { theory,procedure, product, innovation }\end{array}$ \\
\hline Collaboration & $\begin{array}{l}\text { Competency for collaboration for solving problem, solution } \\
\text { for conflict, make decision, conflic solution, and negotiate for } \\
\text { achieving a particular goal }\end{array}$ \\
\hline Communication & $\begin{array}{l}\text { Competency for expressing ideas or opinion, the use of IT, } \\
\text { tolisten and understanding message }\end{array}$ \\
\hline
\end{tabular}




\begin{tabular}{ll}
\hline $\begin{array}{l}\text { Management } \\
\text { Feelings }\end{array}$ & $\begin{array}{l}\text { Competency for manage internal feelings so that a person } \\
\text { can manage her/his behavior and manage external feelings } \\
\text { when a person communicate to others }\end{array}$ \\
\hline Problem Solving & $\begin{array}{l}\text { Competency for solve problem of society for the betterment of } \\
\text { live }\end{array}$ \\
\hline
\end{tabular}

Keterkaitan antara media daring dengan pembelajaran Abad ke-21 dilihat dari pemanfaatan teknologi yang digunakan dalam penyelesaian masalah. Guru maupun siswa sama-sama belajar dengan adaptasi baru. Media daring menjadi sesuatu yang sudah tidak asing lagi di tengah pembelajaran saat ini. Melainkan menjadi suatu kebutuhan bagi guru maupun siswa. Keberadaan kelas beralih menjadi kelas virtual. Kegiatan belajar mengajar dikomunikasikan dengan modal gawai, laptop, komputer, tablet dan juga internet. Pembelajaran sejarah yang kaya akan materi, seperti materi yang dimulai dari Ilmu Sejarah, Sejarah Lokal, Sejarah Indonesia, Sejarah Dunia, bahkan Sejarah Kontemporer. Penyederhanaan Kompetensi Dasar tidak mengurangi esensi dari pembelejaran sejarah. Hal ini dikarenakan, terdapat banyak peristiwa sejarah yang dapat dikaji. Hal yang menantang adalah bagaimana cara gurumengemas materi sejarah yang memanfaatkan media agar dapat tersampaikan kepada siswa dengan menarik.

Media daring menjadi solusi untuk pembelajaran jarak jauh. Guru sejarah dapat dengan leluasa menyampaikan materi, tugas maupun evaluasi dengan beragam media.Media daring ini dapat memanfaatkan yang sudah ada, seperti fitur dalam google, youtube, zoom meeting, instagram, quizizz, moodle, kahoot, dan lainnya. Media daring menujukkan bahwa belajar dapat dimanapun dan kapanpun. Sebagaimana yang peemrintah berlakukan yaitu program BDR. BDR menuntut guru untuk menfaatkan berbagai teknologi yang ada demi suksesnya pembelajaran. Peran guru dalam pembelajaran terlihat dalam tiga aspek diantaranya perencanaan, pelaksanaan, dan evaluasi pembelajaran.

Aspek perencanaan dilakukan guru dengan mempersiapkan Rencana Pelaksanaan Pembelajaran (RPP) untuk selanjutnyadiinformasikan kepada siswa melalui GC dan WAG. Kedua aplikasi ini paling seringdigunakan oleh guru karena user friendly. Aspek perencanaan menjadi tahap awal yang dapat menentukan kesuksesan pembelajaran. GC dan WAG dimanfaatkan guru untuk membagikan materi maupun penugasan. Sedangkan aspek pelaksanaan guru menggunakan Zoom Meeting dan Google Meeting. Meskipun Kemendikbud menyediakan aplikasi kerjasama seperti rumah belajar, ruang guru, zenius, meja kita, dan lainnya. Akan tetapi, bagi guru Zoom Meeting dan Google Meeting lebih familir digunakan. Adapun kreativitas guru pada tahap ini yaitu dengan memadupadankan berbagai aplikasi seperti Google Classroom, WhatsApp Group, dan Zoom Meeting dianggap saling melengkapi. Namun kelemahannya adalah ketika jaringan internet tidak berjalan dengan baik, maka akan berdampak pada proses pembelajaran.

Pada aspek evaluasi, kebanyakan guru menggunakan quizizz, dan kahoot. Ada juga yang menggunakan google forms. Meskipun tidak dapat mengamati siswa secara langsung ketika mengerjakan soal, akan tetapi aplikasi-aplikasi ini membantu guru dalam proses evaluasi 
karena hasilnya dapat langsung diakses.

Google classroom merupakan platform pembelajaran yang mewadahi asyncghronous learning dan paling banyak digunakan oleh guru. Hal tersebut tidak terlepas dari berbagai faktor yang menunjang penggunaan google classroom menjadi platform yang dipilih dalam proses pembelajaran, yaitu:

1. Kemudahan penggunaan platform google classroom. Berbagai fitur di google classroom dikemas dengan bentuk sederhana dan praktis sehingga, platform tersebut sangat mudah digunakan oleh siswa. Hal tersebut tidak terlepas dari User Interface (UI) dan User Experience $(U X)$ google classroom. User Interface (UI) adalah segala sesuatu yang dirancang untuk menjadi sebuah perangkat informasi sehingga pengguna dapat berinteraksi melalui tampilan layar pada mesin, aplikasi, atau program komputer yang digunakan. Secara sederhana, User Interface (UI) berfungsi sebagai tampilan visual yang menjadi penghubung antara platform dengan pengguna. Sedangkan, User Experience (UX) adalah pengalaman yang terkait dengan respon, aspek, perilaku, pikiran, dan emosi pengguna saat menggunakan aplikasi, mesin, atau sistem.

2. Manfaat fitur dan layanan yang disediakan google classroom. Platform google classroom memberikan manfaat yang besar pada implementasi pembelajaran berbasis daring. Berdasarkan penelitian Umairah \& Zulfah Z (2020), sebanyak 94\% siswa memiliki motivasi belajar yang tinggi saat pembelajaran daring melalui platform google classroom. Motivasi merupakan salah satu aspek yang memberikan pengaruh positif pada proses belajar. Menurut Slavin (2009), semakin besar motivasi belajar yang dimiliki siswa, semakin meningkat pula aktivitas siswa dalam belajar sehingga, pembelajaran menjadi efektif. Dengan demikian, penggunaan platform google classroom oleh guru sejarah yang berhasil meningkatkan motivasi belajar siswa memenuhi indicator efektivitas belajar, yaitu intensif. Artinya, penggunaan google classroom meningkatkan motivasi belajar siswa pada pembelajaran sejarah daring.

3. Kualitas layanan platform google classroom. Google classroom sebagai bagian dari produk Google, tentu ditunjang dengan kualitas sistem yang mumpuni. Dengan performa sistem google classroom yang berkualitas sebagai platform pembelajaran darin tentu menunjang terwujudnya pembelajaran yang efektif.

Pembelajaran menggunakan Learning Managemen System (LMS) seperti google classroom termasuk pada asynchronous learning, yaitu pembelajaran yang dapat berlangsung kapanpun, artinya tidak mengharuskan siswa masuk kelas pada waktu bersamaan. Pembelajaran asinkronus umumnya difasilitasi media seperti e-mail dan kolom diskusi yang menunjang komunikasi dan diskusi antara siswa dengan guru dan siswa lainnya. Dengan keluwesan pada aspek waktu, aspek, dan tempat, pembelajaran asinkronus memenuhi komponen penting pembelajaran daring yaitu fleksibilitas (Hartanto, 2016). Selain itu, menurut Dennis \& Robbert (2005), pembelajaran asinkronus seperti menggunakan google clasroom berkaitan erat dengan cognitive participation, artinya pembelajaran asinkronus dapat meningkatkan kemampuan siswa untuk memproses suatu informasi. Ketika pembelajaran 
secara asinkron, siswa memiliki banyak waktu untuk memahami informasi, tugas, dan materi belajar secara lebih optimal, karena tugas atau jawaban tidak harus langsung disampaikan seperti di pembelajaran sinkronus. Siswa dapat mencari, menonton, atau membaca sumber belajar di perangkat lain sehingga jawaban, tugas, atau diskusi menjadi lebih bermutu.

Guru tentu mempunyai pertimbangan yang kompleks terkait pemilihan platform pembelajaran daring berdasarkan aspek kebutuhan, keterampilan, dan fasilitas belajar yang dimiliki siswa dan guru. Akan tetapi, guna terwujudnya pembelajaran sejarah daring yang efektif, aspek personal participation atau aktivitas sosial pada kegiatan pembelajaran asinkronus penting untuk dikembangkan oleh guru.

Disamping itu, Google for Education yang menaungi platform google classroom terus berupaya menghadirkan visibilitas dan inovasi untuk mendukung guru di berbagai sekolah dengan melakukan pembaharuan berupa:

1. Classroom add-ons, fitur ini memungkinkan platform penunjang belajar lainnya seperti Kahoot dan Edpuzzle terhubung dengan google classroom.

2. Schedule assignments, dengan fitur ini guru dapat menjadwalkan waktu pengerjaan dan tenggat tugas secara otomatis untuk beberapa kelas hanya dalam satu tempat.

3. Classroom offline mode in mobile apps, platform google classroom dapat diakses walaupun tidak terhubung internet. Siswa dapat mengerjakan, menulis dan mereview tugas di google docs secara offline.

4. Student engagement tracking, fitur ini mempermudah guru untuk mengetahui kapan terakhir siswa membuka google classroom, kapan siswa mengumpulkan tugas, dan kapan siswa aktif dengan bertanya atau menjawab di fitur komentar.

Platform pembelajaran daring yang mewadahi asynchronous learning dan paling banyak digunakan oleh guru adalah zoom cloud meeting. Zoom cloud meeting adalah platform penyedia layanan dan fitur yang menunjang pembelajaran daring berbasis video conference. Penggunaan media video untuk belajar sangat membantu dalam proses pembelajaran, khususnya pada siswa generasi Z, yaitu generasi yang lahir pada zaman serba teknologi, sehingga gaya dan media pembelajaran yang digunakan sangat visual (Monica \& Fitriawati , 2020).

Dibandingkan platform penyedia layanan video conference lainnya. Hal tersebut, tidak lepas dari aspek User Interface (UI) dan User Experience (UX) zoom cloud meeting yang sederhana dan mudah dipahami siswa. Sehingga, tidak heran platform zoom cloud meeting banyak dimanfaatkan sebagai serambi untuk melakukan pembelajaran daring secara sinkronus. Kemudahan penggunaan zoom cloud meeting tentu membantu siswa mempelajari materi belajar dengan optimal sehingga meningkatkan kualitas pembelajaran. Dengan meningkatnya mutu pembelajaran, meningkat pula efektivitas belajar siswa.

Kedua, manfaat fitur dan kualitas layanan platform zoom cloud meeting. Pada situasi dan kondisi yang mengharuskan dilaksanakannya pembelajaran jarak jauh (PJJ), kegiatan belajar dengan video conference menggunakan zoom cloud meeting sangat membantu guru dan siswa untuk berinteraksi walaupun tidak berada di tempat yang sama. Pada aspek kualitas layanan, 
hasil penelitian Hidayatullah (2020) menghasilkan, bahwa kualitas sistem, kualitas informasi, dan kualitas pelayanan zoom cloud meeting berpengaruh positif terhadap kepuasan pengguna dan manfaat bersih. Berbagai manfaat dari fitur dan layanan yang disediakan zoom cloud meeting berkaitan erat dengan aspek fleksibilitas, produktivitas dan efisiensi waktu yang mendukung terciptanya pembelajaran yang efektif. Sebagimana menurut Slavin (2009) pembelajaran dikategorikan efektif apabila siswa melakukan proses belajar secara efisien sesuai waktu yang telah ditetapkan.

Pembelajaran dengan model tele-conference menggunakan zoom cloud meeting tergolong synchronous learning, yaitu pembelajaran yang terjadi secara real-time pada waktu dan platform yang sama. Berdasarkan penelitian Dennis \& Robert (2005), pembelajaran asinkronus berkaitan erat dengan personal participation, artinya dapat meningkatkan antusiasme dan motivasi siswa. Komunikasi pada pembelajaran sinkronus layaknya komunikasi pada pengajaran tatap muka, guru dan siswa dapat berbicara langsung, berbeda dengan pembelajaran asinkronus. Sehingga, hal tersebut akan menstimulus dan memotivasi siswa secara psikologis. Sehingga, tidak heran antara penggunaan zoom cloud meeting yang mewadahi pembelajaran sinkronus dengan efektivitas belajar memperoleh korelasi yang kuat dibandingkan dengan hasil korelasi penggunaan google classroom yang mewadahi pembelajaran asinkronus dengan efektivitas belajar siswa.

Sementara itu, pembaharuan sistem, peningkatan bandwidth dan pelayanan baik dari segi audio dan visual juga terus dilakukan zoom cloud meeting. Untuk menghadirkan pertemuan virtual secara nyata, zoom meluncurkan fitur baru yaitu immersive view. Fitur tersebut memungkinkan guru untuk mengatur siswa ke dalam satu latar belakang virtual dan adegan untuk terhubung dalam kelas. Sehingga, dapat menciptakan suasana berada di ruang kelas nyata. Dengan peningkatan layanan dan pembaharuan sistem membuat platform zoom cloud meeting semakin banyak dipakai.

Pemilihan platform pembelajaran yang tepat sesuai kebutuhan dan kemampuan semakin meningkatkan tingkat efektivitas belajar. Proses pembelajaran dengan interaksi asinkronus saja hanya berkutat pada pemberian informasi, tugas, dan materi belajar tanpa adanya interaksi dan umpan balik baik dari guru maupun sesama siswa. Hal tersebut tentu berdampak pada aspek perkembangan sosial siswa. Sebagaimana menurut Dennis \& Robert (2005), bahwa pembelajaran asinkronus hanya mengembangkan cognitive participation siswa saja, tanpa mewadahi personal participation siswa. Namun, pembelajaran dengan interaksi sinkronus saja hanya berpengaruh pada aspek personal participation saja, tanpa mengembangkan cognitive participation yang optimal seperti di pembelajaran asinkronus. Maka, perlu kombinasi penggunaan platform yang mewadahi interaksi secara sinkronus dan sinkronus pada pembelajaran sejarah daring.

Dari pemanfaatan google classroom dan zoom cloud meeting sebagai platform pembelajaran daring secara efektif dan efisien memberikan dampak positif dalam proses belajar mengajar. Sehingga, siswa cepat menerima platform digital tersebut. Semakin cepat yaitu guru dan siswa dalam menerima teknologi, semakin mudah pula penerimaan sistem e-learning 
(Agustina \& dkk, 2016). Dengan demikian, hasil perhitungan yang menunjukkan hubungan yang kuat antara penggunaan google classroom dan zoom cloud meeting dengan efektivitas belajar merupakan kombinasi kompleks yang meliputi: kemudahan penggunaan, kelengkapan fitur, dan kenyamanan layanan yang disediakan aplikasi tersebut serta kesiapan penerimaan dari siswa dan guru yang ditunjang dengan fasilitas yang baik sangat mendukung kesuksesan sistem e-learning pada pembelajaran sejarah.

Meskipun demikian, perlu kerjasama berbagai elemen untuk meningkatkan efektivitas pembelajaran daring seperti pemerintah terkait, instansi pendidikan, sekolah, guru, dan siswa. Pemerintah perlu bekerjasama dengan lembaga pendidikan tinggi dan organisasi guru untuk menyediakan pedoman pelaksanaan pembelajaran sejarah daring secara jelas dan runtut, mengadakan kegiatan pelatihan atau bimbingan teknis terkait sumber belajar, metode, media dan pendekatan pembelajaran berbasis daring, dan perlu regulasi yang jelas berkaitan dengan rasionalitas waktu belajar mengajar.

Bagi sekolah, upaya proses pembelajaran berbasis teknologi digital perlu diperkuat melalui program seperti pelatihan dan pendampingan untuk meningkatkan kompetensi guru. Pelatihan yang diadakan dapat terkait penyusunan dan pemanfaatan platform, strategi, model, dan media pendukung pembelajaran daring. Di samping itu, sekolah perlu mengupayakan penyediaan dan memperbaiki fasilitas pembelajaran daring bagi guru dan siswa dan layanan khusus terkait keterbatasan siswa dan guru selama pembelajaran daring. Agar proses pembelajaran daring berjalan dengan baik dan konsisten, dilakukan pula pemantauan dan evaluasi kinerja guru selama pelaksanaan kegiatan belajar mengajar berbasis daring.

\section{Kesimpulan}

Pandemi yang melanda Indonesia dianggap oleh guru sejarah sebagai suatu tantangan. Hal ini terbukti dari terlihat adanya upaya kreativitas guru dalam memadupadankan berbagai aplikasi daring demi tercapainya tujuan pembelajaran. Penyebab utamanya adalah kelebihan dan kekurangan yang dimiliki oleh setiap aplikasi online. Berdasarkan hasil penelitian menunjukkan keberagaman dari setiap aplikasi diantaran ada yang menggunakan kuota besar, fitur tidak lengkap, dan berbayar. Akan tetapi, guru menutup kekurangan yang ada dengan kelebihan dari aplikasi yang lain. Hal ini menunjukkan bahwa guru mampun untuk memadupadankan ragam aplikasi yang ada.

Pemanfaatan aplikasi daring yang dilakukan oleh guru dalam pembelajaran sejarah dikategorikan ke dalam tiga aspek yaitu perencanaan, pelaksanaan, dan evaluasi pembelajaran. Ditemukan lima aplikasi yang menurut guru efektif, efisien dan terjangkau bagi siswa diantaranya Google Classroom, WhatsApp Group, Zoom Meeting, Google Meeting, dan Quizizz. Apabila dikategorikan kedalam tiga aspek. Pertama, aspek perencanaan mayoritas menggunakan Google Classroom dan WhatsApp Group. Kedua, aspek pelaksanaan pembelajaran yang diminati adalah Zoom Meeting dan Google Meeting. Ketiga, aspek evaluasi pembelajaran menggunakan Quizizz.

Selain itu, ada juga upaya inovatif yang dilakukan oleh guru dengan adanya LMS yang dikembangkan sekolah secara mandiri sesuai dengan kebutuhannya. Sehingga guru 
memanfaatkan LMS tersebut untuk kegiatan belajar. Meskipun setiap aplikasi memiliki kelebihan dan kekurangannya masing- masing, akan tetapi guru mampu melengkapinya untuk dimanfaatkan dalam proses pembelajaran sejarah di tingkat SMA, MA dan SMK. Sehingga pembelajaran sejarah secara daring dapat berjalan lebih optimal.

\section{Daftar Rujukan}

Agustina, R., \& dkk. (2016). Sejarah, Tantangan, dan Faktor Keberhasilan Dalam Pengembangan E-Learning. Seminar Nasional Sistem Informasi Indonesia. Universitas Gadjah Mada.

Anis, M. Z. A., Susanto, H., \& Fathurrahman. (2021). Studi Evaluatif Pembelajaran Sejarah Daring Pada Masa Pandemi Covid-19. Fajar Historia: Jurnal Ilmu Sejarah dan Pendidikan, 5(1), 60-69. https://doi.org/10.29408/fhs.v5i1.3358.

Morissan. (2014). Metode Penelitian Survei. Prenada Media Group.

Cahyani, A., Listiana, I. D., \& Larasati, S. P. D. (2020). Motivasi Belajar Siswa SMA pada Pembelajaran Daring di Masa Pandemi Covid-19. IQ (Ilmu Al-Qur'an): Jurnal Pendidikan Islam, 3(01), 123-140. https://doi.org/10.37542/iq.v3i01.57.

Dennis, A. R., \& Robert, L. P. (2005). Paradox of Richness: A Cognitive Model of Media Choice. IEEE Transactions on Professional Communication, 48(1), 10-21.

Hartanto, W. (2016). Penggunaan E Learning Sebagai Media Pembelajaran. Jurnal Pendidikan Ekonomi: Jurnal Ilmiah Ilmu Pendidikan, Ilmu Ekonomi dan Ilmu Sosial 10(1),

Hasan, S.H. (2019). Pendidikan Sejarah untuk Kehidupan Abad Ke-21. HISTORIA: Jurnal Pendidik dan Peneliti Sejarah, 2(2), 61-72.

Hasan, S. H. (2018). Social Studies Curriculum for the Generation of the 21th Century. Presented at International Seminar on Social Studies, Moral and Character. Yogyakarta, 1 September 2018.

Hidayatullah, S. (2020). Implementasi Model Kesuksesan Sistem Informasi DeLone and McLean Terhadap Sistem Pembelajaran Berbasis Aplikasi Zoom di Saat Pandemi Covid19. Jurnal Teknologi dan Manajemen Informasi, 6(1), 45-53.

Indiani, B. (2020). Mengoptimalkan proses pembelajaran dengan media daring pada masa pandemi covid-19. Sipatokkong BPSDM Sulawesi Selatan, 1(3), 227-232.

Jamaluddin, D., Ratnasih, T., Gunawan, H., \& Paujiah, E. (2020). Pembelajaran Daring Masa Pandemik Covid-19 Pada Calon Guru: Hambatan, Solusi dan Proyeksi. Karya Tulis Ilmiah UIN Sunan Gunung Djjati Bandung, 1-10. http://digilib.uinsgd.ac.id/30518/.

Monica, J., \& Fitriawati, D. (2020). Efektivitas Penggunaan Aplikasi Zoom Sebagai Media Pembelajaran Online Pada Mahasiswa Saat Pandemi. Jurnal Communio: Jurnal Ilmu Komunikasi, 9(2), 1630-1640.

Morissan. (2014). Metode Penelitian Survei. Prenada Media Group.

Slavin, R. E. (2009). Educational Psychology: Theory and Practice. New Jersey: Pearson Education. 
Satrianingrum, A. P., \& Prasetyo, I. (2020). Persepsi Guru Dampak Pandemi Covid-19 terhadap Pelaksanaan Pembelajaran Daring di PAUD. Jurnal Obsesi: Jurnal Pendidikan Anak Usia Dini, 5(1), 633. https://doi.org/10.31004/obsesi.v5i1.574.

Syarifudin, A. S. (2020). Impelementasi Pembelajaran Daring Untuk Meningkatkan Mutu Pendidikan Sebagai Dampak Diterapkannya Social Distancing. Jurnal Pendidikan Bahasa dan Sastra Indonesia Metalingua, 5(1), 31-34.

Umairah, P., \& Zulfah Z. (2020). Peningkatan Motivasi Belajar Menggunakan Google Classroom di tengah Pandemi Covid-19 Pada Peserta Didik Kelas XI IPS 4 SMAN 1 Bangkinang Kota. Journal on Education, 2(3), 275-285.

Wahyono, P., Husamah, H., \& Budi, A. S. (2020). Guru Profesional di Masa Pandemi COVID19: Review Implementasi, Tantangan, dan Solusi Pembelajaran Daring. Jurnal Pendidikan Profesi Guru, 1(1), 51-65.

Wati, N. W. I. (2020). Dampak Covid-19 Terhadap Implementasi Pembelajaran Berbasis Online (Daring) di SMP Negeri 2 Kerambitan. Jurnal Ilmu Pendidikan, 1(1), 19-27. 